\title{
MODEL PEMBELAJARAN PROBLEM BASED LEARNING DALAM MENINGKATKAN HASIL BELAJAR SISWA SMA MUHAMMDIYAH MATARAM
}

\author{
Mappanyompa \\ Program Studi KPI, Universitas Muhammadiyah Mataram, Indonesia \\ Myompakaltim@gmai.com
}

\section{INFO ARTIKEL}

\section{Riwayat Artikel:}

Diterima: 01-03-2020

Disetujui: 30-04-2020

\section{Kata Kunci:}

Model Pembelajaran,

Problem Based Learning,

Meningkatkan Hasil Belajar.

\section{Keywords:}

Learning Model,

Problem Based Learning,

Improving learning

Outcomes

\begin{abstract}
ABSTRAK
Abstrak: Penelitian ini brtujuan untuk meningkatkan hasil belajar sisiwa melalui penerapan model pembelajaran Problem Based Learniang (PBL) pada mata pelajaran Kemuhammadiyahan di SMA Muhammdiyah Mataram. Jenis penelitian ini adalah Penelitian Tidakan Kelas (PTK), penelitian ini dilakukan secara kolaboratif antara guru dan observasi. Penelitian ini meliputi empat tahap yaitu, perencanaan, pelaksanaan, obserfasi dan refleksi. Jenis instrumen yang di gunakan untuk menumpulkan data yang digunakan adalah Tes hasil belajar siswa dan lembar pedoman observasi guru dan siswa. Data yang diperoleh dianalisis secara kuantitatif untuk menentukan ketuntasan individu dan ketuntasan klasikal. Hasil penelitian meneunjukan bahwa menerapan metode pembelajaran Problem Based Learning (PBL) dapat meningkatkan hasil belajar siswa.

Abstract: This research aims to improve the results of the learning of students through the implementation of the model learning Problem Based Learniang (LBL) on the subject of Kemuhammadiyahan in the SMA Muhammadiyah Mataram. This type of research is the study of Sleep Class (PTK), the study was conducted collaboratively between teachers and observations. The research includes four stages namely, planning, implementation, obserfation and reflection. The type of instrument that is used to dull the data in use is the student study results test and the teacher and student observation sheet. The obtained Data is analyzed quantitatively to determine the individual's individuation and the classical dictates. The results of the research on the wave that the method of learning Problem Based Learning (LBL) is able to improve student learning outcomes.
\end{abstract}

\section{A. LATAR BELAKANG}

Belajar adalah suatu aktifitas yang dilakukan seseorang dengan sengaja dalam keadaan sadar untuk memperoleh suatu konsep, pemahaman, atau pengetahuan baru sehingga memungkinkan seorang terjadinya perubahan perilaku yang relatif tetap baik dalam berfikir, merasa, maupun dalam bertindak. ${ }^{1}$

Pembelajaran merupakan bantuan yang diberikan pendidik agar terjadi peroses pemerolehan ilmu dan pengetahuan, penguasaan, kemahiran, dan tabiat, serta pembentukan sikap dan keyakinan pada perserta didik. Dengan kata lain, pembelajaran adalah peroses untuk membantu perserta didik agar dapat belajar dengan baik. ${ }^{2}$

Model pembelajaran adalah suatu perencanaan atau suatu pola yang digunakan sebagai pedoman dalam merencanakan

1 Ahmad Susanto. Teori Belajar dan Pembelajaran ( Jakarta: Rawanangan, 2013), hlm. 4

${ }^{2}$ Ibid, hlm. 18 pembelajaran di kelas atau pembelajaran dalam tutorial. Model pembelajaran mengacu pada pendekatan pembelajaran yang akan digunakan, termasuk di dalamnya tujuan-tujuan pengajaran, tahap-tahap dalam kegiatan pembelajaran, lingkungan pembelajaran dan pengelolaan kelas. Hal ini berarti bahwa model mengajar merupakan model belajar, dengan model tersebut guru dapat membantu siswa untuk mendapatkan atau memperoleh informasi, ide, keterampilan cara berpikir, dan mengekpresikan ide diri sendiri, selain itu, mereka juga mengajarkan bagaimana mereka ngajar. ${ }^{3}$

Berdasarkan data awal hasil belajar siwa pada pelajaran Ke-Muhammadiyahan di SMA Muhammdiyah Mataram, dapat disimpulkan hasil belajar masih rendah, nilai rata-rata ujian adalah 60 dengan nilai tertinggi 65 dan nilai terendah 50, dengan daya serap siswa adalah 53\% dan ketuntasan kelasikal yang di capai adalah 54\%. Kelas dianggap tuntas apabila ketuntasan kelasik

3 Trianto, Model Pembelajaran Terpadu (Jakkarta: Bumi Aksara, 2015), hlm. 51-52 
$65 \%$ dan siswa dianggap tuntas secara individual apa bila mampu mencapai 6,5. Rendahnya nilai rata-rata kelas menunjukan bahwa kopetensi dasar siswa pada mata pelajaran Ke-Muhammadiyahan masih belum memenuhi apa yang diharapkan.

Nilai yang didapatkan dari guru KeMuhammadiyahan menujukkan bahwa siswa yang dapat mencapai KKM hanya 11 orang atau $50 \%$ dari 22 orang siswa. Yang mana disebabkan kurangnya pemahaman materi pelajaran yang diberikan oleh guru kepada siswa sehingga hasil belajar siswa rendah atau dibawah rata-rata. ${ }^{4}$

Rendahnya hasil belajar siswa dapat di sebabkan oleh beberapa faktor yaitu:

1. Pembelajaran yang masih berpusat pada guru (techer centered) karna pengetahuan dianggap dapat dipindahkan secara utuh dari pikiran guru ke pikiran siswa. Dalam pembelajaran guru lebih cenderung menggunakan mode ceramah dari pada memberikan kesempatan seluas-luasnya kepada siswa untuk menemukan sendiri konsep-konsep yang dipelajari. Siswa lebih cenderung pasif dalam kegiatan pembelajaran hanya terjadi transper ilmu oleh guru dan bukan karna aktifitas dari siswa itu sendiri.

2. Materi pembelajaran yang kurang di kaitkan dengan masalah-masalah nyata sehingga siswa mengganggap pelajaran Ke-Muhammadiyahan bersifat abstrak dan terkesan membosankan. Siswa sangat sulit untuk memahami konsepkonsep Ke-Muhammadiyahan karna biasa dihadapkan pada suatu yang abstrak dan tidak ada kaitanya dengan kehidupan mereka seharihari. Padahal tujuan pembelajaran KeMuhammadiyahan agar siswa memahami konsep-konsep Ke-Muhammadiyahan serta menerapkan dalam kehidupan sehari-hari.

3. Sistem evaluasi yang terhadap guru. Penilayan hasil belajar siswa lebih ditekankan pada pengukuran kemampuan kognitif siswa melalui penelitian pekerjaan rumah, ulangan harian dan ulangan semester. Guru tidak memperhatikan aspek aktivitas siswa sehari-hari ketika mereka belajar. Maka hal ini guru perlu pelaksanaan sistem penelitian terhadap semua hasil belajar siswa selama peroses belajarnya. Penilaian secara komprehensif terhadap kopetensi siswa meliputi aspek kogenitif, apektif dan psikomotorik hal ini dimaksudkan agar siswa lebih aktif dalam pembelajaran dan

${ }^{4}$ Dokumentasi, Lembaran Evaluasi Belajar PKn di Kelas V, Hari Senin, 06 maret, 2018 kemendirian siswa dalam belajar dapat ditumbuhkan. 5

Dalam kegiatan pembelajaran guru cenderung menggnakan metode yang menonton sehinga menyebabkan siswa menjadi fasif dalm kegiatan belajar mengajar di dalam kelas. Hal tersebut akan berpengaruh pada hasil belajar siswa kahususnya pada mata pelajaran KeMuhammadiyahan. Dengan demikian maka perlu diterapkan model pembelajaran yang dapat meningkakan hasil belajar yaitu model pembelajaran berbasis masalah (PBL) karna pembelajaran berbasis masalah perupakan pembelajaran yang meneuntut perserta didik untuk berfikir keritis, memecahkan masalah dan belajar secara mandiri. Peroses peecahan masalah dilakukan secara kolaborasi dan di sesuaikan dengan keidupan.

Duch mendefinisikan pembelajaran berbasis masalah adalah suatu model pembelajaran yang menghadapkan pserta didik pada tantangan "belajar untuk belajar ". Siswa aktif berkerja sama di dalam kelompok untuk mencari salusi pemecahan dunia nyata. ${ }^{6}$

Berdasarkan wawancara dengan guru yang bersangkutan tentang kriteria ketuntasan maksimum (KKM) yang diterapkan di SMA Muhammdiyah Mataram. Yang di terapkan yakni Kriteria Ketuntasan Minimum (KKM) 6,5. Serta di SMA Muhammdiyah Mataram belum pernah diterapkan model pembelajaran yang lainnya, hanya media yang pernah diterapkan di SMA Muhammdiyah Mataram, tetapi jarang digunakan karna lebih mudah dengan metode ceramah. Sehingga di SMA Muhammdiyah Mataram hanya menggunakan model ceramah dan hanya menggunakan buku paket yang menjadi pegangan guru selama mengajar di SMA Muhammdiyah Mataram .7

Sesuai dengan informasi dari guru KeMuhammadiyahan yang bersangkutan. Untuk mengatasi maslah tersebut, peneliti akan Melakukan penelitian sebagai solusi untuk memecahkan permasalahan tersebut, meningkatkan hasil belajar siswa, perlu dilakukan situasi pembelajaran yang menyenangkan dan merangsang keaktifan dan untuk berperan akatif dalam proses pembelajaran. Menyikapi masalah tersebut diperlukan model pembelajaran yang tepat agar pembelajaran Ke-Muhammadiyahan

5 Rusmono, Setrategi Pembelajaran dengan Problem Based Learning Itu Perlu Untuk Meningkatkan Profesionalitas Guru, (Bogor: Gahalia Indonesia, 2014), hlm. 1-4

6 Yatim Riayanto, Pradigam Baru Pembelajaran, (jakarta: kencana 2009), hlm 285

2018

\footnotetext{
${ }^{7}$ Karlin, Wawancara Guru Kelas V, MI NW Kawo, 05 Februari
} 
dapat meningkatkan hasil belajar siswa di SMA Muhammdiyah Mataram.

Berdasarkan latar belakan tersebut, maka peneliti tertarik untuk melakukan penelitian dengan judul "Model Pembelajaran Problem Based Learning Dalam Meningkatkan Hasil Belajar Siswa SMA Muhammdiyah Mataram.

\section{B. METODE PENELITIAN}

Adapun lokasi atau tempat penelitian yang akan diteliti yaitu di SMA Muhammdiyah Mataram yang berjumlah 150 orang siswa adapun peneliti mengambil lokasi ini adalah:

1. Karna penelti melihat cara pembelajaran disana degan menggunakan metode ceramah, tanya jawab, sehingga peneliti mencoba dengan metode PBL dalam peroses pembelajaran dalam rangka menerik minat dan motivasi siswa dalam kelas sehingga demikian dapat mendapatkan hasil yang baik dalam kegiatan pembelajaran.

2. SMA Muhammdiyah Mataram merupakan madrasah yang berada di tengah-tengah kehidupan masyarakat sehingga mudah untuk mendapatkan informasi serta data yang dibutuhkan.

Sasaran penelitian: Penelitian ini adalah semua siswa kelas XI SMA Muhammdiyah Mataram tahun pelajaran 2018/2019 dengan jumlah keseluruhan 30 orang. Melihat populasi yang relatif kecil, maka semua murid dan ditambah guru Ke-Muhammadiyahan yang diambil sebagai subyek penelitian dan akhirnya penelitian merupakan penelitian populasi.

Jenis penelitian: Penelitian ini tergolong penelitian tindakan kelas (celassroom atcion reaserch) yang secara umum bertujuan untuk memperbaiki peroses pembelajaran KeMuhammadiyahan di Kelas XI SMA Muhammdiyah Mataram, sehingga dapat meningkatkan hasil belajar siswa. Penelitian tindndakan kelas adalah penelitian yang memamperkan terjadinya sebabakibat dari pelakuan, sekaligus memamparkan apa saja yang terjadi ketika perlakuan yang diberikan, dan memaparkan seluruh peroses sejak awal pemberian perlakuan sampai dengan dampak dari perlakuan tersebut. Dengan demikian, penelitian tindakan kelas atau PTK adalah jenis penelitian yang memaparkan baik perses atau hasil. ${ }^{8}$

Metode Pengumpulan Data: Pengumpulan data adalah cara-cara yang digunanakan oleh peneliti untuk pengumpulan data. Metode yang digunakan dalam peneltian ini adalah: Observasi ;Pada tahap ini dilaksanakan proses observasi

${ }^{8}$ Suharismi Arikunto, Suhardjono, Penelitian Tindakan Kelas, (Jakarta: Bumi Aksara, 2017), hlm. 1 terhadap pelaksanaan tindakan dengan menggunakan lembar observasi yang telah dibuat umtuk melihat aktivitas siswa selama proses pembelajaran berlangsung. Yang menjadi sasaran pengamatan aktivitas siswa dalam penelitian ini adalah aktivitas siswa mendengarkan motivasi dari guru, siswa siap untuk mengikuti proses pembelajaran, aktivitas siswa dalam menyelesaikan masalah lembar kerja siswa yang diberikan, keaktifan dalam memecahkan permasalahan yang diberikan oleh guru, keaktifan siswa dalam menyelesaikan soal pertanyaan yang diberikan oleh guru, siswa aktif memperhatikan penjelasan guru yang belum dipahami dari tugas lembar kerja siswa, keaktifan Siswa memberikan jawaban dari pertanyaan yang diberikan oleh guru, siswa mengajukan dan mengemukakan pikiran dan pendapatnaya, siswa mempresentasikan hasil diskusinya dan menyimpulkan materi yang sudah dipelajari.

Istrumen penelitian: Lembar Observasi siswa digunakan dalam penelitian tindakan kelas ini untuk mengetahui aktifitas guru dan siswa dalam kegiatan belajar mengajar dengan menggunakan model pembelajaran berbasis masalah.

Teknik Analisis Data: Analisis data dan observasi yakni Untuk mengetahui kualitatif susatu metode dalam kegiatan pembelajaran, perlu dilakukan analisis data. Data dari hasil pengamatan guru dan siswa pada saat pelajaran sedang berlangsung sesuai indikator observasi yang telah disusun kemudian dipersentasikan peningkatan peda setiap pertemuan. Untuk menghitug persenats hasil observasi terfokus pada guru dan siswa digunakan rumus:

$$
\mathbf{P}=\frac{\sum \text { skorperolehan }}{\sum \text { skortotal }} \times \mathbf{1 0 0} \%
$$

Keterangan p-tingkat keberhasilan. ${ }^{9}$

\section{HASIL DAN PEMBAHASAN}

1. Hasil

Siklus 1 dilaksanakan sebanyak 4 kali pertemuan. Tiga kali pertemuan untuk kegiatan pembelajaran dan satu kali pertemuan untuk tes siklus. Pertemuan dilakukan pada tanggal 13 febrwari 2019 dengan alokasi waktu 2 X 40 menit.

\section{a. Perencanaan}

Pada tahap ini peneliti menyimpan segla hal yang di perlukan dalam pelaksanaan tindakan. (1). Bersama guru membuat Rencana Pelaksanaan Pembelajaran (RPP), dengan pokok bahasan Menghargai kewajiban, hak, dan tanggug jawab sebagai warga masyarakat dan umat beragama dalam kehidupan sehari-hari, yang mencerminkan 
pencerapan metode pembelajaran berbasis masalah sesuai dengan kereteria yang sudah ditemukan sebelumnya dalam meningkatkan hasil belajar siswa . (2)Besama guru menyiapkan lembar observasi aktifitas guru selam peroses pembelajaran berlangsung. (3)Bersama guru menyiapkan lebear observasi akifitas belajar siswa selama kegiatan pembelajaran berlangsung. (4) Bersama guru menyusun tes pilihan ganda yang digunakan untuk mengevaluasi hasil belajar siswa.

(5) Bersama guru menyiapkan kunci jawaban tes.

\section{b. Pelaksanaan Siklus I}

Pada tahap ini peneliti melaksakan tindakan sesuai RPP yang telah disusun. Kegiatan pada siklus I dilaksanakan dalam 4 kali pertemuan. Berikut penjabaran dari pelaksanaan siklus I, Pertemuan Pertama: Pertemuan pertama dilaksanakan pada hari rabu , 13 feberuari 2019, dengan alokasi waktu 2x40 menit. Kegiatan diawali dengan membaca do'a bersama serta mengucapkan salam yang dijawab serempak oleh siswa. Selanjutnya mengabsensi siswa. Guru juga menyampaikan tujuan pembelajaran yaitu Menghargai kewajiban, hak, dan tanggug jawab sebagai warga masyarakat dan umat beragama dalam kehidupan sehari-hari. Kemudian Guru mengawali materi Menghargai kewajiban, hak, dan tanggug jawab sebagai warga masyarakat dan umat beragama dalam kehidupan sehari-hari dengan menerapkan Model Pembelajaran Problem Based Learning (PBL), setelah itu menjelaskan tentang model pembelaaran yang akan dilaksanakan yaitu model pembelajaran Problem Based Learning (PBL), kemudian menyampaikan gambaran umum dari materi yang akan dipelajari menggunakan model tersebut, kemudian guru membagi kelompok, pembagian kelompok dilakukan dengan teknik berhitung dan membentuk 4 kelompok dan guru bersama siswa menetapkan subtopik-subtopik yang spesifik, tugas penyelidikan dan jadwal waktu. Guru bersamasama dengan siswa menarik kesimpulan tentang materi yang dipelajari pada hari ini. Guru memancing siswa dengan pertanyaan-pertanyaan yang mengarah pada kesimpulan tentang materi pada hari ini dan menanyakan hal-hal yang belum dipahamisiswa terkait meetode pembelajaran yang dilaksanakan. Setelah hal tersebut dilakukan guru mengakhiri pembelajaran dengan mengiformasikan garis besar isi kegiatan padapertemuan berikutnyadan mengucapkan salam.

Pertemuan kedua: Pertemuan kedua dilaksanakan pada hari kamis, 16 februari 2019 dengan alokasi waktu 2x40 menit. Kegiatan diawali dengan guru membuka pelajaran dengan salam dan berdoa kemudian dilanjutkan dengan mengabsen siswa lalu mengkondisikan siswa untuk siap belajar. Selanjutnya guru memberikan apersepsi kepada siswa tentang materi yang akan diajarkan. Pada Pada kegiatan inti guru pmenyampaikan skenario atau permasalahan menganai Menghargai kewajiban, hak, dan tanggug jawab sebagai warga masyarakat dan umat beragama dalam kehidupan sehari-hari siswa bergabung dengan kelompok yang telah ditentukan pada pertemuan terdahulu. Selanjutnya guru mendorong siswa untuk mengumpulkan informasi yang sesuai atau melaksanakan eksperimen, untuk mendapatkan penjelasan dan pemecahan masalah. Kemudian guru membagikan LKS soal-soal permasalahan tentang ekosistem sebanyak 10 soal. Siswa mengerjakan secara kelompok dalam waktu 30 menit untuk mengerjakan LKS. Selama proses pengerjaan LKS guru mendampingi siswa untuk memberikan masukan apabila diperlukan oleh siswa. Dalam proses pengerjaan, ada beberapa siswa yang bertanya tentang soal yang ada di dalam LKS. Setelah 30 menit lebih guru menghentikan jalannya diskusi. Kemudian guru meminta LKS yang telah dikerjakan siswa untuk dipresentasekan depan kelas. Guru memberi waktu 5 menit kepada setiap kelompok kemudian diminta mempresentasikan hasil diskusinya dan tanya jawab dari kelompok lain. Tahap penutup dengan durasi 5 menit, guru memberikan kesempatan kepada siswa yang ingin bertanya. Guru bersama-sama dengan siswa menarik kesimpulan tentang materi yang dipelajari pada hari ini. Guru memancing siswa dengan pertanyaan-pertanyaan yang mengarah pada kesimpulan tentang materi pada hari ini. Guru mengakhiri pembelajaran dengan berdoa dan mengucapkan salam.

Pertemuan Ketiga: Pertemuan ketiga dilaksanakan pada hari rabu , 20 febuari 2019 dengan alokasi waktu 2x40 menit. Kegiatan diawali seperti biasa dengan guru membuka pelajaran dengan salam dan berdoa kemudian dilanjutkan dengan mengabsen siswa lalu mengkondisikan siswa untuk siap belajar. Selanjutnya guru memberikan apersepsi kepada siswa tentang materi yang akan diajarkan yaitu tentang menentukan ekosistem dan saling berhubungan antara komponen dan tak lupa menginformasikan tujuan pembelajaran yaitu siswa dapat menjelaskan hubungan antara komponen ekosisrem, siswa dapat menggambarkan dalam bentuk diagram rantai makanan dan jarring-jaring kehidupan berdasar hasil pengamatan suatu Menghargai kewajiban, hak, dan tanggug jawab sebagai warga masyarakat 
dan umat beragama dalam kehidupan sehari-hari bagi kehidupan. Guru mengawali materi pengertian Menghargai kewajiban, hak, dan tanggug jawab sebagai warga masyarakat dan umat beragama dalam kehidupan sehari-hari, komponen-komponen hak dan kewajiban sebagai warga masyarakat danumat beragama dalamkehidupan sehari-hari yang meliputi: hak, kewajiba dan beragama yang meliputi: Individu, Populasi, Komunitas dan Biosfer dan ketergantungan antara komponen Menghargai kewajiban, hak, dan tanggug jawab sebagai warga masyarakat dan umat beragama dalam kehidupan sehari-hari yang meliputi: hak, kewajiba dan beragama bagi kehidupan dengan menerapkan model pembelajaran Problem Based Learning (PBL) yang pada awalnya disertai dengan pemberian permasalahan-permasalahan kontekstual yang berhubungan dengan materi yang dipelajari. Guru membagi siswa menjadi 4 kelompok dan membagikan lembar kerja siswa pada masingmasing kelompok untuk didiskusikan. Siswa mulai berdiskusi, mengumpulkan sumber pemecahan masalah dan mengumpulkan informasi selengkaplengkapnya. Setiap siswa dalam kelompok berpartisipasi dalam kegiatan diskusi kelompok yang hasilnya akan dipresentasikan di depan kelas. Guru membimbing siswa dalam menyajikan hasil kerja di depan kelas. Pada saat presentasi kelompok, diberikan waktu yang digunakan untuk tanya jawab antara kelompok presentator dengan siswa kelompok lainnya. Pada sesi tanya jawab inilah siswa akan berpendapat, berargumen, bertanya dan menjawab pertanyaan yang akan menambah partisipasi dan keaktifan berdiskusi siswa. Kemudian guru membantu siswa mengkaji ulang hasil pemecahan masalah. Tahap penutup dengan durasi 5 menit, Guru meminta kepada siswa untuk mengumpulkan semua lembar soal yang sudah dikerjakan. Guru bersama-sama dengan siswa menarik kesimpulan tentang materi yang dipelajari pada hari ini. Guru memancing siswa dengan pertanyaan-pertanyaan yang mengarah pada kesimpulan tentang materi pada hari ini dan tidak lupa pula guru memberi tahu siswa bahwa pada pertemuan selanjutnya akan dilaksanaka ujian. Guru mengakhiri pembelajaran dengan berdoa dan memberikan motivasi kepada siswa.

Pertemuan Keempat: Pertemuan keempat pada hari kamis , 23 Febuari 2019. Pertama yang akan dilaksanakan adalah tahap pendahuluan. Kegiatan diawali dengan mengucapkan salam yang dijawab serempak oleh siswa. Selanjutnya mengabsensi siswa kemudian mengajukan pertanyaan tentang kesiapan siswa tes hari ini. Pada pertemuan kali ini, guru melakukan tes untuk megetahui hasil pembelajaran yang telah dilakukan pada 3 pertemuan sebelumnya. Tes dilaksanakan selama 60 menit dengan memberikan 10 butir soal tentang pemecahan masalah. Siswa melakukan persiapan evaluasi dengan berdo'a. Lalu guru memberikan instruksi agar semua buku dimasukkan ke dalam tas. Dilanjutkan peserta didik mengerjakan soal evaluasi dengan tenang dan sungguh-sungguh. Guru berkeliling mengawasi peserta didik mengerjakan soal. Setelah siswa selesai mengerjakan soal, siswa diminta untuk mengumpulkan lembar jawaban dan guru mengakhiri pertemuan dengan salam.

\section{c. Obserfasi dan Evaluasi}

Tahap obserfasi dan efaluasi pada aktifitas guru dan siswa sebagai berikut:

Obsevasi aktifitas guru: Untuk mengetahui hasil obsrvasi aktivitas guru dapat diketahui aktivitas siswa pada saat proses pembelajaran berlangsung adapun presentase frekuensi siswa yang paling tinggi diatas $00 \%$ dari keaktifan siswa belajar yaitu $60 \%$ siswa yang aktif di kelas; $57,40 \%$ siswa yang mencatat materi yang disajikan; $50,92 \%$ siswa yang memperhatikan peneliti. Obsevasi aktifitas guru: Berdasarkan hasil observasi aktivitas guru, pada tabel di atas maka dapat diketahui persentase tingkat keberhasilan aktivitas guru setelah dilakukn analisis pada siklus 1 mencapai 66\%. Hasil obsrvasi guru dapat dikatakan cukup.

\section{d. Observasi Aktivitas Belajar Siswa}

Dalam tahab observasi aktivitas belajar siswa dilakukan oleh penelitian sebagai observasi selama mengikuti peroses pembelajaran denagn menggunakan metode pembelajaran berbasis masalah. Berdasarkan hasil aktivitas belajar siswa pada tabel di atas maka di peroleh data pada siklus 1 mencapai $60 \%$ dapat disimpulkan keaktivitas secara keseluruhan adalah dengan kreteria siswa masih cukup aktif. Hal ini menunjukan bahwa kektifan siswa masih perlu ditingkatkan lagi, dan dilanjutkan pada siklus selanjutnya.

Tahap efaluasi dengan memberikan tes kepada siswa: Pada siklus 1, guru melakukan evaluasi dengan memberikan tes kepada siswa. Tes yang di berikan adalah untuk mengetahui hasil belajar siswa berupa tes pilihan ganda yang berjumlah 10 soal dengan alokasi waktu 15 menit. Berdasarka tabel di atas dapat di ketahui bahwa hasil belajar siklus I bahwa nilai rata-rata siswa 66.19 dengan perincian siswa yang tuntas sebanyak $47.61 \%$ (11 siswa) dan yang tidak tuntas $52.38 \%$ (10 siswa). Pada persentase ketuntasan 
belajar siswa kelas VA pada siklus 1 dapat diketahui bahwa, hasil belajar siswa belum menenuhi keriteria ketuntasan minimum belajar yaitu 6,5\% untuk itu penelitianperlu melanjutkan siklus 1I untuk memperbaiki kelemahan yang terjadi padasiklus I dan memperbaiki hasil belajar siswa.

\section{Deskripsi Pembelajaran pada siklus II}

Siklus II dilaksanakan sebanyak 3 kali pertemuan. Tiga kali pertemuan untuk kegiatan pembelajaran dan satu kali pertemuan untuk tes siklus.

\section{a. Perencanaan Siklus II}

Pada perencanaan ini berisi tentang rencanarencana yang akan di lakukan, serta rencanarencana yang telah disesuaikan dengan hasil refleksi pada siklus I. Hal-hal yang perlu disiapkan meliputi: a), Membuat Rencana Pelaksanaan Pembelajaran (RPP) mengenai materi yang akan diajarkan. RPP disusun sesuai dengan langkahlangkah pelaksanaan model pembelajaran Pembelajaran Problem Based Learning (PBL). b), Menyiapkan Lembar Kerja Siswa. Untuk mengerjakan LKS siswa dibentuk dalam kelompokkelompok. c), Menyusun lembar observasi untuk melihat kondisi kelas dengan mengamati keterampilan siswa selama proses pembelajaran. d), Menyiapkan soal tes akhir siklus II.

\section{b. Pelaksanaan tidakan siklus II}

Pertemuan ke lima: Proses pembelajaran pada pertemuan ke lima dilaksanakan pada tanggal 27 februari 2019, sebelum memulai pembelajaran guru mempersiapkan dan mengecek siswa untuk memulai pembelajaran dengan memberikan motivasi terlebih dahulu kepada siswa dan menjelaskan pengertian menghargai hak dan tanggung jawab sebagai warga masyarakat dan umat beragama dalam kehidupan sehari-hari., guru menyampaikan tujuan pembelajaran yang akan dicapai yaitu siswa dapat menjelaskan pengertian menghargai hak dan tanggung jawab sebagai warga masyarakat dan umat beragama dalam kehidupan sehari-hari. Pada pertemuan ini guru menceritakan kepada siswa pentingnya belajar menghargai hak dan tanggungjawab sebagai warga masyarakat dan umat beragama dalam kehidupan sehari-hari., serta memahami materi, guru menjelaskan materi dan siswa menyimak dan menyalin materi yang dijelaskan oleh guru dengan baik. Setelah guru menjelaskan materi kepada siswa, guru memberikan kesempatan kepada siswa untuk bertanya mengenai materi yang sudah dijelaskan. pemateri memberikan latihan kepada siswa yang telah disiapkan untuk siswa dan guru memberikan bimbingan. Sementara siswa mengerjakan latihan lembar kerja siswa guru mengajukan pertanyaan yang dapat mendorong siswa untuk berpikir dan mancari informasi yang dibutuhkan untuk menemukan jawaban dari permasalahan yang diberikan. Setelah siswa mengerjakan latihannya guru memberikan kesempatan kepada siswa untuk menuliskan hasil kerjanya didepan kelas, setelah itu guru memberikan kesempatan untuk mengumpulkan tugas siswa yang telah dikerjakan dimeja guru.

Pada pertemuan tersebut hasil pengamatan guru diantaranya semua siswa sudah aktif melaksanakan tugas secara keseluruhan, namun belum sempurna. Rangkuman yang dibuat sudah menyeluruh dan lebih sistematik. Pertanyaan yang dimunculkan sudah lebih banyak dan bervariasi. Sebagian besar siswa sudah aktif mengerjakan soal-soal yang diberikan meskipun belum seluruhnya benar. Dalam partisipasi mengawali pembelajaran, semua siswa aktif dan tertib mengikuti pembelajaran. Pada saatpeneliti melakukan Tanya jawab dengan pemanfaatan situasi sebagian besar siswa aktif dan terampil menyampaikan pendapat dan memecahkan masalah dalam partisipasi pada proses belajar, siswa yang belum aktif sudah menunjukan adanya peningkatan. Dalam mempersentasikan hasil pekerjaannya sudah merata meskipun belum seluruhnya, dan dalam menutup semua siswa rangkuman menyeluruh dan sistematik.

Pertemuan ke enam: Pembelajaran pada pertemuan ke enam siklus II pada tanggal 2 Maret 2019, guru bertugas sebagai observer rmemasuki ruangan kelas, setelah memberi salam guru menyiapkan siswa dan berdoa terlebih dahulu sebelum proses belajar mengajar berlangsung, setelah itu guru melakukan observasi dan mengabsen kehadiran siswa. Guru bertanya kepada siswa mengenai materi yang sudah dijelaskan sebelumya pada pertemuan pertama, setelah meriview pelajaran sebelumnya guru melanjutkan pembelajaran dengan membahas kelanjutan materi yaitu menentukan menghargai hak dan tanggung jawab sebagai warga masyarakat dan umat beragama dalam kehidupan sehari-hari. Proses pembelajaran pada pertemuan tersebut yaitu siswa mulai memperhatikan pembelajaran hal ini dilihat dari keaktifan siswa dalam menerima tugas semua siswa sudah aktif melaksanakan tugas secara keseluruhan, namun belum sempurna. Rangkuman yang dibuat sudah menyeluruh dan lebih sistematik. Pertanyaan yang dimunculkan sudah lebih banyak dan bervariasi. Sebagian besar siswa sudah aktif mengerjakan soal-soal meskipun belum seluruhnya benar. Dalam partisipasi 
mengawali pembelajaran, semua siswa aktif dan tertib mengikuti pembelajaran. Pada saat guru melakukan tanya jawab dengan pemanfaatan benda-benda sekitar, sebagian besar siswa aktif dan terampil menyampaikan pendapat dan memecahkan masalah. Dalam partisipasi pada proses pembelajaran/diskusi, masing-masing siswa tampak aktif bekerja, siswa yang belum aktif sudah menunjukkan adanya peningkatan. Dalam mempresentasikan hasil pekerjaannya sudah merata meskipun belum seluruhnya. Dalam menutup pembelajaran, semua siswa menulis rangkuman menyeluruh dan sistematik. Seluruh siswa membuat pajangan mandiri. Dalam menerima tugas berikutnya, hampir seluruh siswa bersemangat dan perhatian.

Pertemuan ke tujuh: Pertemuan ke tujuh yaitu pada tanggal 6 Maret 2019, pada pertemuan ini,guru sebagai observer mengadakan evaluasi dengan menggunakan instrument penelitian yang sudah disiapkan (terlampir). Waktu yang ditentukan dalam pertemuan ini adalah 2 x 40 menit atau dua jam pelajaran.

\section{Pembahasan}

Pembelajaran berbasis masalah ( PBL) merupakan salah satu model pembelajaan yang menghadapkan pesrta didik pada tantangan “ belajar untuk belajar". Siswa aktif bekerja sama didalam kelompok untuk mencari solusi permasalahan dunia nyata. Pengetahuan yang rill bagi para siswa adalah sesuatu yang dibangun atau ditemukan oleh siswa itu sendiri. Jadi pegetahuan bukan lah seperangkat fakta, konsep atau kaidah yang diingat siswa, tapi harus merekonstruksi pengetahuan itu kemudaian memberi makna melelui pengelaman nyata. Dalam hal ini harus dilatih untuk memecahkan masalah dan menemukan suatu yang berguna bagi dirinya. ${ }^{10}$

Beberapa temuan yang di peroleh dalam penelitian ini yaitu siswa menadilebih aktif ketika pembelajaran berlagsung, dengan penerapan model pembelajaran berbasis masalah (PBL) dapat melatih sikap bekerjasama dan menghargai pendapat teman, siswa lebih mudah memahami materi pembelajaran dengan metode pembelajaran berbasis masalah (PBL) dan nilai siswa meningkat setelah menggunakan metode pembelajaran berbasis masalah (PBL).

Hasil analisis penelitian setelah dilakukan penelitian tindakan kelas yaitu dengan menerapkan metode pembeajaran berbasis masalah dengan materi tentang Menghargai kewajiban, hak, dan tanggug jawab sebagai warga masyarakat dan umat beragama dalam kehidupan

${ }^{10}$ Sadirman, Interai dan Motifasi Belajar Mengajar, (Jakarta: PTRaja Grafndo Persada 2017), hlm. 223 sehari-hari. Hasil belajar Ke-Muhammadiyahan siswa mengalami penigkatan kahususnya materi tentang Menghargai kewajiban, hak, dan tanggug jawab sebagai warga masyarakat dan umat beragama dalam kehidupan sehari-hari.

Hal ini dapat dilihat dari hasil analisis observasi aktifitas guru di peroleh nilai rata-rata $60 \%$ mengalami peningkatan pada siklus II menjadi $80 \%$ dengan atagori aktif. Hal ini menunjukan bahwa indikator keberhasilan penelitian mengalami peningkatan pada siklus II balik pada aktifitas guru maupun siswa. Setelah dilakukan beberapa perbaikan dari kekurangan pada siklus sebelumnya hasil belajar siswa mengalami peningkatan. Diketahui hasil belajar siswa pada siklus I memperoleh nilai rata-rata $66.19 \%$ dengan ketuntasan belajar $47.61 \%$ terjadi peningkatan pada siklus II siswa memperoleh nilai rata-rata $76.19 \%$ degan ketuntasan belajar mencapai $90.47 \%$. dengan demikian, maka dapat disimpulkan hasil belajar siswa mengalami peningkatan pada siklus II untuk ketuntasan individu meningkat menjadi $76.19 \%$ dan untuk ketuntasan kelasikal meningkat menjadi $90.47 \%$

\section{SIMPULAN DAN SARAN}

\section{A. Simpulan}

Berdasarkan paparan data pembahasan pada bab sebelumnya, dapat disimpulkan bahwa penerapan metode pembelajaran berbasis masalah dapat meningkatkan aktifitas belajar guru dan siswa serta hasil belajar siswa pada matapelajaran Ke-Muhammadiyahan kelas VA di MI NW Kawo tahun Ajaran 2018/2019. Hal ini dapat dilihat dari peningkatan hasil observasi aktivitas guru pada siklus I mencapai $60 \%$ meningkat pada siklus II menjadi $80 \%$ sedangkan peningkatan ketuntasan kelasika, pada siklus I dengan ketuntasan belajar mencapai $47.61 \%$ mengalami peningkata dengan ketuntasan belajar mencapai $90.47 \%$.

\section{B. Saran}

Pertama: Hasil penelitian ini diharapkan dapat memberikan pengaruh positif terhadap upaya peningkatan pelajaran baik pada pelajaran Ke-Muhammadiyahan maupun padamata pelajaran lainya. Be Untuk mencapai hasil belajar siswa yang di harapkan hendaknya menggunakan model pembelajran yang pariatif dan mendorong siswa agar belajar secara mandiri. Kedua: Diharapkan pada guru baik guru Ke-Muhammadiyahan maupun guru lainya agar mampu memilih serta menerapkan metode yang sesuai dengan materi yang disampikan di dalam kelas, dengan pemlihan metode yang tepat maka menunjang keefektifan dan peroses belajar mengajar dalam mata pelajaran Ke-Muhammadiyahan. Ketiga: Diharapan 
pada siswa agar tetap rajin dalam mengikuti setaip mata pelajaran yang diajarkan oleh guru termasuk pembelajaran Ke-Muhammadiyahan sehingga di peroleh hasil belajara yang memuaskan. Keempat: Dalam menerapkan metode pembelajaran berbasis masalah (PBL), guru tidak harus terpaku pada apa yang sudah di tetapkan dalam model pembelaaran tersebut, tetapi bisa dan harus disesuaikan dengan kebutuhan dan keadaan yang ada. Kelima: Untuk mencapai hasil belajar siswa yang di harapkan hendaknya menggunakan model pembelajran yang pariatif dan mendorong siswa agar belajar secara mandiri. Keenam: Diharapkan pada guru baik guru Ke-Muhammadiyahan maupun guru lainya agar mampu memilih serta menerapkan metode yang sesuai dengan materi yang disampikan di dalam kelas, dengan pemlihan metode yang tepat maka menunjang keefektifan dan peroses belajar mengajar dalam mata pelajaran KeMuhammadiyahan. Ketuju: Diharapan pada siswa agar tetap rajin dalam mengikuti setaip mata pelajaran yang diajarkan oleh guru termasuk pembelajaran Ke-Muhammadiyahan sehingga di peroleh hasil belajara yang memuaskan.

Dalam menerapkan metode

\section{DAFTAR RUJUKAN}

Arikunto Suharsmi. Prosedur Penelitian Suatu Pendekatan Peraktik, (Jakarta: Rinka Cipta, 2014).

Djamarah Bahri Syaiful. Prestasi Belajar dan Kopetensi Guru, (Surabaya: Usaha Nasional, 2012).

Mappanyompa. (2019). Pengaruh Pendidikan Kemuhammadiyahan Terhadap Sikap Perilaku Siswa, Ibtida'iy Journal PGMI, 4 (1),17-29.

Hajar. Penerapan Pendekatan Pembelajaran Berbasis Masalah dalam Meningkatkan Prestasi Belajar SKI Siswa Kelas V MI MW Langgalawe 02 Aik Buaka Tahun Pelajaran 2013/2014. (Skripsi IAIN MATARAM 2013).

Huda Miftahul. Model-Model Pembelajaran dan Pembelajaran Isu-Isu Metodis dan Paradigmatis, (Yogyakarta: Celeban Timur, 2016).

Karlin. Wawancara Guru Kelas XI, SMA Muhammadiyah Mataram, 05 FebruarVi 2018.

Muhammad Nurman, Evaluasi Pendidikan, (Mataram: CV. Sannabil, 2015).

Martono Nanang. Model Penelian Kuantitatif: Analisis Isi dan Analisis Data Sekunder, (Jakarta: Rajawali Pers, 2010).

Nata Abuddin. Prespektif Islam Tentang Strategi Pebelajaran. (Jakart: Kencana 2011).
Pentiawati Yuni Hsamah,. Baelajar Dan Pembelajaran, (Malang: Universitas Muhammadiyah Malang, 2016).

Purwanto. Evaluasi Hasil Belajar, (Yogyakarta: Pustaka Belajar, 2011).

Permendikbud No. 81A/2013 Tentang Implementasai kurikulum https//googelewebblighat. Com, di Akses Tanggal 13 /09/2018, Pukul 11:12 Pm.

Rusmono. Setrategi Pembelajaran dengan Problem Based Learning Itu Perlu Untuk Meningkatkan Profesionalitas Guru, (Bogor: Gahalia Indonesia, 2014).

Ramayulis. Metodelogi Pendidikan Agama Islam, (Jakarta: Kalam Mulia, 2014).

Rianto Yatim. Paradigam Baru Pembelajarn, (jakarta: Kencana, 2010). Suginono,Model Penelitian Kuantitatif, Kualitatif dan $R \& D$, (Bandung: Alfabeta, 2017).

Susanto Ahmad. Teori Belajar dan Pembelajaran ( Jakarta: Rawanangan, 2013).

Suci. Materi Pokok Belajar dan Pembelajaran, (Jakarta: Universitas Terbuka, 2017).

Suhardjono, Arikunto Suharismi. Penelitian Tindakan Kelas, (Jakarta: Bumi Aksara, 2017).

Sadirman, Interai dan Motifasi Belajar Mengajar, (Jakarta: PTR Grafndo Persada 2017).

Snjaya Wina. Strategi Pembelajaran Berorentasi Setandar Peroses Pendidikan, (Jakarta: Kencana, 2016).

Trianto. Model Pembelajaran Terpadu (Jakkarta: Bumi Aksara, 2015)

Undang-Undang Republik Indonesia NO. 20 Tahun 2003 Tentang Sistem Pendidikan Nasional Pasal 1-11.

Mappanyompa. (2019). Problematika Pengkaderan Di Perguruan Tinggi Muhammadiyah Mataram Dalam Perspektif Norma Pengkaderan Muhammadiyah, Media Keadilan: Jurnal Ilmu Hukum, 10 (1), 82-98

Umar Husain. Metode Penlitian Untuk Skripsi dan Tesis Bisnis (Jakarta: Rajawali Pars 2011). 